\title{
EDUCAÇÃO E NÃO EMANCIPAÇÃO: OS LIMITES OBJETIVOS DA EDUCAÇÃO ESCOLAR NO CAPITALISMO INDUSTRIAL CONTEMPORÂNEO
}

\author{
Cesar Augusto Alves da Silva ${ }^{1}$
}

"Não há lugar numa fábrica para um sábio."

\begin{abstract}
RESUMO: O presente escrito teve como objetivo analisar a necessidade da educação escolar para o desenvolvimento do ora vigente modo de produção capitalista industrial. Esta análise se baseia na investigação e exposição de Marx dos momentos constitutivos do capital por meio do modo de produção industrial de mercadorias. Em suma, procuramos demonstrar a partir dos escritos, principalmente, de Marx, Adorno e Marcuse que a demanda do modo de produção capitalista por uma massa de indivíduos oriundos da educaçáo escolar não existe, pois a maioria de suas demandas radica nele mesmo, modo de produção, e é solucionada por ele mesmo em seu processo de constituição, não em um elemento externo e ideal, como é o caso da educação escolar.
\end{abstract}

Palavras-chave: Educação escolar. Capitalismo industrial contemporâneo. Semiformação. Emancipação.

\section{EDUCATION AND NOT EMANCIPATION: THE LIMITS OF SCHOOL EDUCATION}

\begin{abstract}
This writing was to analyze the need of education for the development of the now existing industrial capitalist mode of production. This analysis is based on research and Marx's exposure of the constituent moments of the capital through the industrial mode of production of goods. In short, we seek to demonstrate from the writings mainly Marx, Adorno and Marcuse that the demand of the capitalist mode of production by a mass of coming people of school education does not exist, since most of their demands rooted in himself, mode production, and are resolved by itself in its constitution process, not an external and ideal element, as in the case of school education.
\end{abstract}

Keywords: School education. Contemporary industrial capitalism. Semiformation. Emancipation.

\footnotetext{
${ }^{1}$ Instituição privada de ensino superior - São Paulo (SP), Brasil. E-mail: cesaraa@usp.br DOI: 10.1590/ES0101-73302018164078
} 


\title{
ÉDUCATION ET NON ÉMANCIPATION: LES LIMITES DE L'ÉDUCATION SCOLAIRE
}

\begin{abstract}
RÉSUMÉ: Cette écriture est d'analyser la nécessité de l'éducation pour le développement du mode capitaliste industriel existant actuellement de la production. Cette analyse est basée sur la recherche et Marx occurrence des temps de capital par le mode industriel de production de biens. En bref, nous cherchons à démontrer des écrits principalement Marx, Adorno et Marcuse qu'il n'y a pas la demande du mode de production capitaliste par une masse de gens qui viennent de l'enseignement scolaire, puisque la plupart de leurs demandes enracinées en lui-même, le mode la production, et sont résolus par lui-même dans son processus de création, et non pas un élément extérieur et idéal, comme dans le cas de l'éducation scolaire.
\end{abstract}

Mots-clés: Scolarisation. Le capitalisme industriel contemporain. Semiformation. Emancipation.

\section{Educação e produção material: limites objetivos à produção autônoma de ideias}

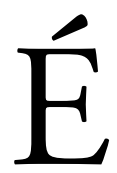

comum a todo "discurso" — oriundo dos meios jornalísticos, acadêmicos, populares ou quaisquer outros - que se pronuncia contra a violência crônica que assola as pequenas e grandes cidades indicar a falta de educação escolar como provável causa desta última e, portanto, seu suprimento como solução, muitas vezes, única, possível. Se é ponto pacífico que a educação e o conhecimento podem diminuir o medo do desconhecido - e com isso reduzir a hostilidade entre os homens, tornando a socialização dos indivíduos possível —, também é verdade que tal hostilidade não é causada unicamente pelo medo, e que a forma concreta da relação social implica considerar a base material que sustenta a vida dos homens. A escassez de postos de trabalho é outro problema objetivo, estrutural e imanente ao próprio sistema capitalista industrial - que a educação, segundo aqueles que acreditam nela como panaceia, é capaz de resolver. Não obstante, a organização do mundo social contemporâneo é fundamentada numa forma específica, historicamente determinada, de produzir e reproduzir materialmente a vida humana e o próprio mundo que, desde seu início, independeu do nível de escolarização da massa de seus produtores e consumidores. Com efeito, tal organização apresenta uma dinâmica interna - exposta por Marx, principalmente em $O$ Capital - que em poucos momentos alude à educação como elemento constitutivo dela. Analisando a importância do não saber na organização do trabalho capitalista, Marx (1989, p. 414) cita Thompson (1824, p. 274): 
O homem de saber e o trabalhador produtivo se separam completamente um do outro, e a ciência em vez de permanecer em poder do trabalho, em máos do trabalhador para aumentar suas forças produtivas em seu benefício, colocou-se contra ele em quase toda parte $[. .$.$] . O conhecimento torna-se um instrumen-$ to que pode separar-se do trabalho e opor-se a ele.

A organização capitalista da produção material define, por si mesma, em seu processo de produção e reprodução do mundo, e retroativo das necessidades, algo imaterial, a saber, a (pseudo)formação dos indivíduos que a integram (Cf. ADORNO, 1996, p. 388-411), muitas vezes dependendo dessa pseudoformação para assegurar o fluxo do capital. A educação para as massas produzirem mercadorias e, com isso, expandirem o capital, torna-se dispensável já com o aparecimento das manufaturas. Essa forma produtiva compensa as limitaçóes e deficiências do trabalhador individual com a coletivização do trabalho: "O mecanismo específico do período manufatureiro é o trabalhador coletivo, constituído de muitos trabalhadores parciais. [...] A estreiteza e as deficiências do trabalhador parcial tornam-se perfeições quando ele é parte integrante do trabalhador coletivo" (MARX, 1989, p. 400). Quanto mais avança a "modernizaçáo" do trabalho com a utilização de máquinas e processos racionalizados de produção, mais se coletiviza o trabalho, padronizam funçóes antecipadamente pensadas para o trabalhador e menos se exige aprendizagem, destreza e habilidades dele, estratégia que diminui os custos do trabalho:

Póe-se a manufatura a transformar numa especialidade a ausência de qualquer formação. Ao lado da graduação hierárquica, surge a classificação dos trabalhadores em hábeis e inábeis. Para os últimos, não há custos de aprendizagem, e, para os primeiros, esses custos se reduzem em relação às despesas necessárias para formar um artesão, pois a função deles foi simplificada. [...] A desvalorizaçáo relativa da força de trabalho, decorrente da eliminação ou da redução dos custos de aprendizagem, redunda para o capital em acréscimo imediato de mais valia, pois tudo o que reduz o tempo de trabalho necessário para reproduzir a força de trabalho aumenta o domínio do trabalho excedente (MARX, 1989, p. 401-402).

Marx (1989, p. 4), no século XIX, ao observar e analisar os primórdios da segunda Revolução Industrial, nos ensina que "a célula econômica da sociedade burguesa é a forma mercadoria, que reveste o produto do trabalho, ou a forma de valor assumida pela mercadoria”. Ele já percebe, naquele momento praticamente inicial, o poderio da forma valor nesse processo de formação do capital. Nesses termos, Marx praticamente revela o segredo de toda produção industrial capitalista: todo objeto ou serviço produzido na economia burguesa a fim de satisfazer necessidades humanas, "provenham [elas] do estômago ou da fantasia" (MARX, 1989, p. 41), deixa de ser ele mesmo, transmuta-se em outro, é praticamente negado em sua concretude, não 
deixando de sê-lo, se torna "perceptível e impalpável" (MARX, 1989, p. 79), transforma-se em abstração, assume a forma de mercadoria, que tem em sua constituição precípua o valor. Assim, tal objeto acaba por náo satisfazer a necessidade que existia no humano - porque outro e não aquilo que deveria ser: o objeto mesmo - e que ele próprio trouxe "à tona” se colocando à frente da dinâmica psíquica esperada em uma sociedade "livre", emancipada, em que, teoricamente, a condição do sujeito seria afirmada pela possibilidade do indivíduo, socialmente constituído, conscientemente elaborar seu inconsciente numa forma consciente de existir. Todavia, mesmo com o capitalismo sendo baseado no valor de troca, MARX (1989, p. 48) percebe a necessidade do valor de uso dos objetos, e a ele concede presença praticamente ontológica do valor: "[...] nenhuma coisa pode ser valor se não é objeto útil. Se não é útil, tampouco o será trabalho e, por isso, não cria nenhum valor”. Contudo, para explicar o poder que a mercadoria recebe de seu produtor, sem que este se dê conta disso, e a posição determinante que ela passa a ter na dinâmica social (seja de produção ou entre os seres humanos), aquele pensador é obrigado a recorrer a algo próximo à metafísica, a um entendimento do mundo efetuado por meio do mito, a saber, o conceito de "fetiche", criado por antropólogos europeus que, em suas pesquisas, se ocupavam das práticas rituais existentes em grupos humanos ancestrais. Diz MARX (1989, p. 81), com extremo rigor à abstração da forma mercadoria e sem perder a base física da relação:

Há uma relação física entre coisas físicas. Mas a forma mercadoria e a relação de valor entre os produtos do trabalho, a qual caracteriza essa forma, nada tem a ver com a natureza física desses produtos nem com as relaçôes dela decorrentes. Uma relação social definida, estabelecida entre os homens, assume a forma fantasmagórica de uma relação entre coisas. Para encontrar um símile, temos de recorrer à regiáo nebulosa da crença.

Com o modo de produção capitalista industrial se alastrando por todas as partes do globo, a concorrência entre os produtores se recrudesce e o valor de troca, ajudado pela tecnologia, ultrapassa o valor de uso, determinando-o. Se no período de Marx o impacto cultural da nova maneira de produzir e reproduzir os bens necessários à vida dos seres humanos já foi grande, num ambiente de possível totalização da forma mercadoria, ele é a mais pura ontologia do ser social. A forma capitalista industrial de produção, ao totalizar a produção material e imaterial, alcança também as manifestações humanas englobadas pelo que hoje chamamos cultura. É em razão desse cenário que aparecem os trabalhos, por exemplo, dos pensadores que se convencionou denominar "Escola de Frankfurt". Preocupados em explicar tal ontologia, esses intelectuais vão se debruçar sobre os desdobramentos do desenvolvimento tecnológico e cultural a partir da estrutura produtiva, mas sob o olhar crítico marxiano por eles contextualizado, isto é, levando em consideração o espraiamento e o aprofundamento da forma mercadoria sobre todos os âmbitos da vida dos homens e das mulheres. 
A forma capitalista encapsula a produção, manipula e coloca limites objetivos aos seres humanos, alienando-os de si mesmos e dos seus próprios produtos por meio da quantificaçáo do tempo, da separaçáo entre tempo livre e de trabalho, da propriedade privada, da aceleraçấo das atividades cotidianas, da lógica do equivalente imposto a tudo na vida, da forma salário e das necessidades antecipadas e quase suscitadas pela abstração socialmente denominada "mercado" - expressão e forma aparente da dialética da valorizaçáo do valor. Portanto, o aspecto objetivo, isto é, o ambiente que possibilita a experiência formativa do ser humano, é erigido pela forma produtiva, e não pela educaçáo escolar, resultando numa educação do sujeito a partir de tal forma, e náo pela forma escolar, adaptando, delimitando e determinando as funçóes cognitivas e sensórias daquele. Pois como as manifestações do "espírito" humano rapidamente também são absorvidas pela forma social de produção, também se transformam em mercadorias. Ou seja, a cultura passa a obedecer à mesma lógica da produção do restante dos produtos necessários à sobrevivência dos seres humanos. Dessa forma, a experiência possível da consciência é colapsada e reduzida ao esquematismo do valor de troca em seu movimento de reprodução ampliado; a invasão (a apropriação) e a destruição dos pouquíssimos lugares em que ainda restava alguma autonomia ao humano se torna ainda mais fácil, rápida e eficiente, já que "o caráter fetichista da mercadoria não é um fato da consciência, mas é dialético no sentido eminente de que ele produz consciência" (ADORNO; BENJAMIN, 1994, p. 140; ADORNO et al., 1990, p. 111. in MAAR, 2000, p. 8). Portanto, enclausurado pela forma produtiva capitalista do material, isto é, a mercadoria em seu processo de valorização do valor, o imaterial é produzido, a consciência é erigida como ideologia, como falsa consciência, pseudoformação no bojo daquela forma produtiva.

Ora, sob as circunstâncias até aqui apresentadas, a educação escolar não parece ser capaz de sozinha conseguir produzir alteraçóes no sistema produtivo nos dois sentidos postulados pelos seus demiurgos, a saber: no próprio movimento imanente do capital, potencializando-o, expandindo-o e, com isso, gerando postos de trabalho o suficiente para destruir o exército de reserva e alcançar o pleno emprego e, além disso, causar no âmbito do próprio capitalismo industrial uma pletora de seres humanos pacíficos, solidários e tolerantes; e naquele sentido da educação como instrumento capaz de infundir a consciência e fazer com que os seres humanos ultrapassem a forma capital e organizem-se socialmente de maneira contrária ao próprio modo de produção capitalista, ou seja, a revolução por meio da educação.

A forma econômica que erige a condição concreta em que a educação escolar se insere não é apenas coadjuvante, deriva ou está em segundo plano, e sim o contrário: ela determina a função social da escola, indo além dela e determinando também o relacionamento dos seres humanos entre si e com aquela instituiçáo educacional. Isso fica comprovado pelas palavras de Adam Smith (apud MARX, 1989, p. 415), que demonstram a função da escola pública e os limites do gasto com essa instituição no sistema produtivo capitalista: "Para evitar a degeneração completa do 
povo em geral oriunda da divisão do trabalho, recomenda A. Smith o ensino popular pelo Estado, embora em doses prudentemente homeopáticas”. Não há necessidade de indivíduos eruditos para operar máquinas, projetar ou fazer prédios, fábricas, estradas, galerias de ferro e vidro ou cidades inteiras, pelo contrário, muitas vezes é dada preferência aos "meio idiotas": "Realmente, em meados do século XVIII, algumas manufaturas empregavam de preferência indivíduos meio idiotas em certas operaçóes simples que constituíam segredos de fabricação" (MARX, 1989, p. 414).

A composição orgânica do capital, ao admitir a fundamental necessidade do trabalho vivo, aceita, intrinsecamente, um gasto de nervos, músculos e cérebro, mas não apresenta como um dado intrínseco e subentendido a exigência da escolarização. Pelo contrário, numa direção diametralmente oposta à necessidade de escolarização, a realidade originada pela relação social capitalista de produção reduz a possibilidade de experiências formativas dentro e fora do âmbito laboral e passa a engendrar atividades de pura repetição em que o trabalhador e o consumidor utilizam apenas uma memória muscular para executá-las; e naquelas em que há o uso menor dos músculos a tecnologia substituiu o cérebro e reduziu as tarefas a meros apertos de botóes. Mesmo assim, a educação escolar, o mundo das puras ideias e da cultura, é colocada como ponto fundamental numa organização social em que é a materialidade o grande trunfo, o troféu absoluto. Mais do que isso, o ponto fundamental reside no fato - já amplamente discutido, porém não enfocado como um agente antiescolarização — de que essa materialidade, para ser produzida, está sob uma práxis econômica que é determinada pela rentabilidade, sendo este o elemento fundamental do processo criativo. É, então, o ser social, oriundo, delimitado e determinado pela práxis material — não apenas a produtora, mas a consumidora também - , social e historicamente condicionada, que se eleva à construtora da consciência social, e não o contrário.

A rigor, com a forma capitalista a coagir produtores, produto e consumidores, há uma mudança no foco da produção em relação a formas produtivas historicamente anteriores: ela não mais objetiva as necessidades dos seres humanos, e sim a expansão da própria produção num movimento tautológico que possui seu núcleo na valorização do valor de troca para gerar capital (Cf. MARX, 1989, p. 41-78 e p. 165-175). Esse sistema de produção e circulação, em seu movimento de expansão, tacitamente invade e passa a controlar a vida dos seres humanos, até em seus espaços mais íntimos: consciência, comportamento e tudo aquilo que concerne à experiência estética (sensibilidade, percepção, gosto), pois a forma social da produção material (valor) e o resultado desta (a mercadoria) colocam objetivamente os limites à experiência formativa humana, e esta acaba limitada a uma única possibilidade. Pois, como dito anteriormente, a consciência social é fruto da vivência social do ser social e não o contrário (Cf. MARX, 1991, p. 37). Nesses termos, mais atuais do que nunca, a materialidade é percebida como realmente é, ou seja, em seu status atual: preponderante a todo ser humano e, em sua forma capitalista de produção, atuando fortemente sobre aquele ser. Tal influência vai se acirrar ainda mais com o avanço tecnológico, possibilitando o advento do que Adorno e Horkheimer (2006, p. 99-138) conceituaram como indústria cultural. 
Desse modo, é a própria organizaçáo produtiva do mundo contemporâneo que minimiza a capacidade da educação escolar de interferir em tal organização, pois esta lança seus tentáculos a todos os outros âmbitos da vida dos seres humanos, estruturando e organizando a vida social e cultural, e determinando a experiência formativa humana. Ora, se a experiência formativa do sujeito é balizada objetivamente pelos parâmetros do modo de produção, obstruindo a experimentação das contradiçóes existentes na organização econômica social e colocando em seu lugar a falsidade da harmonia por meio da integração (econômica e cultural, pois os homens se irmanam a partir de suas mercadorias, tais como: veículos automotores e times de futebol), nosso problema é: pode a educaçáo escolar, por meio de uma inserção circunscrita ao campo subjetivo, portanto mantendo as determinaçóes objetivas (aquelas da forma da produção, produtora das relaçôes sociais à revelia dos seres humanos) da experiência formativa, levar o sujeito a perceber aquela falsidade, as contradiçóes existentes e alterar sua práxis social, assumindo sua posição antagônica à sociedade? Dito de outro modo, será a educação escolar capaz de ter poderes para desfazer tal sistema produtivo, originando a emancipação; ou, pelo menos, terá ela forças para inflar a inserção dos educandos em tal organização produtiva; ou ainda, minimamente civilizar os indivíduos, afastando a barbárie social que se materializa até nas próprias escolas? Em suma, mantendose as condiçōes objetivas que, num passado recente, originaram Auschwitz, e hoje produzem a barbárie e mantêm a heteronomia, pode uma ação circunscrita apenas ao âmbito das ideias alterar aquelas condiçóes? Podem os sujeitos maciçamente se interessar por tais ideias se há limitaçóes objetivamente colocadas, isto é, a própria organização da forma produtiva calcada atualmente na ampliação do capital por meio da cultura em seu efeito retroativo da criação das necessidades?

Se Maar (2003, p. 3) assevera que "consciência é 'ser consciente', reflexão da determinação do ser que é a existência, e não uma 'existência espiritual' contraposta dualisticamente à matéria 'inconsciente", podemos dizer, entâo, que matéria e espírito existem e se desenvolvem juntos em um mutualismo sob a determinação da concretude da existência. $\mathrm{O}$ indivíduo consciente atua socialmente com consciência dessa determinação e desse mutualismo. Para isso, necessita de uma sociedade configurada para permitir ao ser humano ser indivíduo e sujeito. Isso significa que o homem atua socialmente a partir de sua existência configurada nos termos de uma determinada forma de produção da vida material que lhe permita autonomia. Todavia, se a autonomia é a possibilidade de o indivíduo desenvolver suas capacidades a ponto de atuar conscientemente em contradição com a organização social, como alcançar tal desenvolvimento, por meio da educação escolar, no mundo em que "[...] a organizaçáo social [...] continua sendo heterônoma, nenhuma pessoa pode viver conforme suas próprias determinaçóes [...], a sociedade forma as pessoas mediante inúmeros canais e instâncias mediadoras de um modo tal que tudo absorvem [...]"? (ADORNO, 1995, p. 182). Adorno ainda afirma: 
A maneira pela qual uma jovem aceita e se desincumbe de um encontro obrigatório, a entonaçáo no telefone e na mais familiar situação, a escolha das palavras na conversa, e até mesmo a vida interior organizada segundo os conceitos classificatórios da psicologia profunda vulgarizada, tudo isso atesta a tentativa de fazer de si mesmo um aparelho eficiente e que corresponda, mesmo nos mais profundos impulsos instintivos, ao modelo apresentado pela indústria cultural (ADORNO e HORKHEIMER, 2006, p. 138).

Num complexo encadeamento produtivo com lógica própria e que se expandiu sobre seres humanos e da natureza, apropriando-se deles e praticamente fundando-os, determinando-os e quase que os reconfigurando - atuando tal qual um buraco negro em seu movimento entrópico — , pode a educação escolar apresentar os poderes de inserção e emancipação de tal lógica? Admitindo e aceitando tal postulado, como é possível interpretar o "discurso" atual que coloca a educação (escolar) como entidade espiritual capaz de salvar o indivíduo e a nação das garras da pobreza, da barbárie e de tudo que há de "mal" no mundo?' A educação escolar, sozinha, pode levar à emancipação ou se tornar "cultura afirmativa" do sistema produtor de mercadorias, pois, propagandeada como elemento mediador da inserção dos indivíduos naquele sistema, não tem como objetivo modificá-lo, ou, pelo menos, discutir com as pessoas possibilidades de organização social para além dele (sistema produtor de mercadorias)? É possível, ainda, afirmar uma função ideal emancipatória à educação em face de uma realidade objetivamente reificada, produtora de uma cultura afirmativa do vigente e da adaptação irrestrita dos indivíduos a tal vigente?

Se considerarmos a lógica própria e quase autônoma da forma produtiva atual e sua influência sobre todos os aspectos da vida humana, talvez o melhor questionamento sobre o poder da educação escolar em relação a tal forma seja: é possível que a educação escolar — produzida no contexto da forma produtiva que engendra o capital, sendo necessário, para isso, transformar a tudo e a todos em mercadoria rentável - seja capaz de se dissociar de tal contexto, escapando à dinâmica universalizadora do capital, e alterar a forma organizativa da produção e reprodução da sociedade, rompendo, ou pelo menos obstruindo, o movimento produtor de consciências pelo fetiche da mercadoria, ou seja, produzir consciências "desfetichizadas" sem dispor de meios materiais, apenas ideais, e num ambiente absolutamente reificado, em que as relaçóes sociais continuam a corresponder àquelas que imperam fora da escola? É possível atingir o esclarecimento numa sociedade de trevas, isto é, concretamente, objetivamente, não esclarecida? Que fique bem claro que estamos longe de "desenterrar" teorias da "reprodução educacional". Nossa intenção é demonstrar que a educação escolar em massa, a verdadeira formação, é desnecessária para o próprio capitalismo e, sozinha, incapaz de produzir alteraçóes, via consciência, na realidade produtiva no sentido de levar a supra-assunção desta, a tão propalada "emancipação por meio da educação". Se em primeiro plano e como centro da sociedade está uma 
forma produtiva que engendra um ambiente propício a sua própria reproduçáo expandida e determina a relaçáo dos seres humanos com o mundo, entre si e com o âmbito das ideias, será uma parte de tais conceitos - aqui contemplada como educação escolar - capaz de alterações, mesmo que superficiais (aumentar as vagas de empregos ou solucionar os problemas de violência) nessa forma produtiva? Lembrando Adam Smith, em seu livro Wealth of Nations (Livro V, cap. I, art. II, apud MARX, 1989, p. 415), podemos verificar uma grande contribuição desse autor para uma teoria da formação: "A compreensão da maior parte das pessoas se forma necessariamente através de suas ocupaçôes ordinárias. Um homem que despende toda a sua vida na execuçáo de algumas operaçóes simples [...] não tem oportunidade de exercitar sua inteligência”. É possível que tais ideias encontrem espaço para se efetivarem se a organização produtiva, como determinante para as experiências formativas humanas, não permitir? Como a educação escolar em si mesma pode levar à emancipação se a realidade material, absolutamente refém da forma capitalista de produção, não permite tal situação? Podem apenas as ideias, originadas daquele tipo de educaçáo, destruir a realidade reificada?

\section{Forma valor, semiformação e emancipação por meio da educação: a experiência substitutiva à contradição social, e a cultura afirmativa.}

Sendo o valor de troca a categoria determinante não apenas dos objetos como também da própria relação social, essa forma objetiva e organizativa da produção origina, como seu correspondente subjetivo, a forma social que Adorno (1996, p. 388-411) conceituou como semiformação, impedindo que a experiência das contradições existentes no âmbito social e econômico seja realizada. É, então, a forma adquirida pela produção, ao mediar a construção do seu correspondente subjetivo, a semiformação, que impede a cultura escolar emancipatória e verdadeiramente formativa de se efetivar, pois "quem compreende o que é poesia dificilmente encontrará um posto bem pago como autor de textos publicitários" (ADORNO, 1996, p. 401). A socialização, desse modo, acontece, por seu lado objetivo, no âmbito erigido por meio da forma social da produção, isto é, aquela que transforma tudo em mercadoria, e, em seu lado subjetivo, nos parâmetros da semiformação. Essa realidade desconsidera qualquer motivo ideal fora dessas categorias. Assim, parece-nos que a solução (educação escolar) defendida por governos, empresários, educadores e leigos, para o problema das péssimas condições de vida e das relaçóes entre seres humanos, ou como caminho para emancipação, é falsa, já que não considera que a forma de organização da produção se movimenta por meio de mecanismos de sua lógica própria (a exploração do trabalho; a produção de mais-valia, valor, capital e sua expansão) como produtora também da realidade a sua volta. 
Não que a educação seja sem importância, que o esclarecimento seja inócuo, ou que não haja uma relação tensa entre teoria e prática, mas o próprio processo de produçáo e reproduçáo material da vida e do mundo, ao engendrar um único molde — massivo — de possibilidade estética, uma experiência falsa, pois não humana e não autônoma, impede a assimilação de qualquer conteúdo fora daquele padrão da semiformação. A produção econômica e social da realidade atual não permite brechas para se chegar a uma consciência emancipatória. Se toda determinação é negação, a consciência não se determina a si mesma, e sim por meio do que não é ela mesma, ou seja, realidade material. As ideias que encontram brechas na realidade material, produzida pela forma valor e reforçada pela indústria cultural, para se desenvolverem e formarem a consciência crítica, só podem se efetivar na prática. No entanto, o processo de formação dos indivíduos na sociedade produtora de mercadorias é determinado pelos limites objetivamente estabelecidos pelo modo de produzir, pelas relaçóes de produção e pela indústria cultural, uma dinâmica retroativa e criadora de consciência e necessidades, estas últimas, existentes no humano, mas somente realizáveis com sua subsunção ao capital, expandindo-o. Essa dinâmica é aquela geradora da valorização do valor transformado, ou duplicado, em cultura e produzindo mercadorias, com isso, determinando capacidades do aparelho sensorial/perceptivo, comportamentos, formas e limites da cognição dos seres humanos: "A indústria cultural como um todo [...] duplica na consciência dos homens o que existe" (ADORNO, 1979, p. 175 apud MAAR, 2003, p. 2). A cultura e a realidade material não se desvinculam. Desse modo, a consciência não é produto dela mesma, isolada da materialidade constituinte do mundo; ela não é uma realização metafísica, é produto da existência terrena dos homens, determinada e limitada por ela. A semiformação é um produto objetivo da forma social que ora se impóe sobre o mundo; ela não é apenas consciência: são as condições objetivas da produção e reprodução material da vida humana que a originam. Sendo assim, a semiformação é erigida pela forma da produção que dita os bens necessários à vida no capitalismo tardio: a maneira de produzir mercadorias. Portanto, ela é produto do capital e não da falta de educação escolar: "A semiformação seria a forma social da subjetividade determinada nos termos do capital” (MAAR, 2003, p. 9).

Nesses termos, a emancipação não se dá por meio da educação — ideia próxima daquilo que seria uma iluminação idealista ${ }^{2}$ — e sim pela supressão do sistema que objetivamente a obstrui. A sujeição dos sujeitos não acontece apenas no âmbito das ideias, da consciência, ela é realizada objetivamente, é determinação produzida pela forma de produzir materialmente a vida dos seres humanos. Dessa maneira, os limites da emancipação, isto é, do vir a ser da autonomia e da própria consciência emancipatória, são produzidos ou obstaculizados pelo modo de produção dos objetos necessários à vida material e atuam objetivamente, e não apenas idealmente, sobre o ser humano. A consciência, a subjetividade e sua formação são produzidas fora do mundo escolar: "Cultura e formação precisam ser examinadas fora do âmbito estritamente cultural ou pedagógico definidos na sociedade, para serem investigadas no plano da própria produção social da sociedade 
em sua forma determinada" (MAAR, 2003, p. 11). Essa "forma determinada" é o ponto. Ela define a (semi)formação, reifica a formação semiformando o sujeito por mais escolarizado que ele seja, pois não há mais espaço para experiências não reificadas e que poderiam originar a emancipação. Sendo assim: "A semiformação vai muito além de uma 'perturbaçáo pedagógica' no interior de uma determinada situação social educacional. Refere-se a uma forma ordenada da sociedade contemporânea determinada conforme um certo modo de produção social dos homens e somente neste âmbito pode ser corretamente apreendida" (MAAR, 2003, p. 12). Há um movimento de relação entre a forma de produzir o que os seres humanos necessitam em sua vida - que determina as próprias necessidades - e a sociedade - a forma dos homens interagirem, pensarem, sentirem, se relacionarem, enfim, a cultura. No sistema capitalista, a cultura e a materialidade estão em constante contato, sendo ambas determinadas pela mesma forma social de produção. Em suma, a dinâmica que aciona o movimento gerador do capital atua na produção e na satisfação das necessidades materiais e imateriais da vida, criando-as e satisfazendo-as retroativamente num único plano e não em locais distintos, não há espaço para a cultura se desenvolver de forma distanciada e, assim, crítica da sociedade.

Desse modo, podemos dizer que acreditamos não haver poder emancipatório na educação escolar, tomada de forma solitária, no âmbito da sociedade produtora de mercadorias do capitalismo tardio - tratando-se essa defesa de uma forma ideológica que remete a educação contra a emancipação do capitalismo —, já que ela é empreendida num campo devassado pela forma social que possui como único intuito a geração de capital. $\mathrm{O}$ mundo organizado até seus últimos rincóes e em seus mínimos detalhes, conforme o modo de produção capitalista, não vai chegar ao fim por meio da educação escolar. A emancipação só pode ser conseguida para além de tal forma produtiva, em sua derrocada real que possibilitaria um espaço objetivo de práticas autônomas e experiências formativas e não semiformativas. Mesmo que o currículo se torne todo ele voltado à emancipaçâo, não são apenas e tão somente as ideias que trarão fim à reificação, porque o homem continuará reificado enquanto o ambiente real em que ele habita, no qual se forma, assim se mantiver. Noutros termos: se a consciência se produz a partir de experiências constituídas e limitadas por um ambiente real, ou pelo menos colocado como real e único possível, tal realidade impede uma experiência emancipatória. Sendo assim, apenas as ideias proferidas por uma educação escolar, mesmo que totalmente voltadas a um objetivo emancipador do homem sobre o capital, não surtirão efeito, pois, em tal organização social, as experiências, as sensaçóes, os limites não serão oriundos dele (homem) ou de suas ideias, mas do ambiente social que o oprime, não lhe permitindo - agora não mais homem, mas produtor/ consumidor/cidadão — a liberdade, a autonomia e a emancipação.

O representar, o pensar, o intercâmbio espiritual dos homens, aparecem aqui como emanação direta de seu comportamento material. O mesmo ocorre com a produção espiri- 
tual, tal como ocorre na linguagem da política, das leis, da moral, da religião, da metafísica etc. de um povo. Os homens sáo os produtores de suas representaçóes, de suas ideias, etc., mas os homens reais e ativos, tal como se acham condicionados por um determinado desenvolvimento de suas forças produtivas e pelo intercâmbio que a ele corresponde até chegar às suas formaçóes mais amplas. A consciência jamais pode ser outra coisa do que o ser consciente, e o ser dos homens é o seu processo de vida real. [...] A moral, a religiáo, a metafísica e qualquer outra ideologia, assim como as formas de consciência que a elas correspondem, perdem toda a aparência de autonomia. [...] Não é a consciência que determina a vida, mas a vida que determina a consciência (MARX, 1991,p. 36-37, grifo nosso).

Para que a educação escolar surta os efeitos desejados é necessário que haja um ambiente real propício à própria escolarização dos indivíduos; um estímulo social real à cultura escolarizada ou letrada, coisa que no atual momento inexiste, e não apenas uma propaganda. As experiências são objetivamente produzidas e controladas pela indústria cultural; e aquelas mediadoras de consciências voltadas à escolarização são substituídas pelas atividades impregnadas pela razão instrumental, as que a sociedade produtora de mercadorias em sua ânsia de ganho e lucro considera propícias à venda de um produto, uma mercadoria.

A própria ideia ora veiculada sobre a educação escolar como caminho para a resolução dos problemas do indivíduo - e, com isso, os do país — , incluindo-o ou emancipando-o, não passa de uma tentativa de induzir os que nela acreditarem ao que Adorno e Horkheimer (2006, p. 99-139) identificou, quando de sua análise dos efeitos da indústria cultural sobre seus consumidores, e que Maar (2000, p. 2-3) se refere e destaca, isto é, uma experiência substitutiva, já que por meio da crença naquela ideia como plenamente possível vive-se a experiência de uma organização social harmoniosa, substituindo e mascarando a possibilidade de experimentar a verdade da sociedade, ou seja, as contradiçóes inerentes ao próprio sistema produtor de mercadorias e que impedem, mesmo aos indivíduos escolarizados, o acesso à emancipação. $\mathrm{O}$ "discurso" ideológico da educação como salvação apresenta soluçóes individuais para os problemas sociais e, dessa maneira, impede que os seres humanos apreendam a realidade social em sua forma contraditória e perversa. Tal posição ideológica acaba por servir à contraemancipação, em razão de direcionar a crítica, de forma fetichista, para o âmbito da cultura e preservar incólume a organização produtiva responsável pela produção da cultura e das consciências. A massificação do conceito de educação como salvação apenas realiza a continuidade do vigente por meio de sua afirmação, já que a forma de produzir o mundo material e imaterial não necessita de mudanças; o indivíduo é que deve se entregar ao discurso que permeia a tal "inclusão" e mergulhar sem peias na educação, mas mantendo a estrutura produtiva em sua forma econômica e social sem nenhuma crítica. 
Em tal contexto discursivo e de pensamentos, a educação assemelha-se ao que Marcuse (1997, p. 89-135) conceituou como "cultura afirmativa", porque efetivamente há um reforço ideológico concernente à aceitação da organização do mundo produzido pelos seres humanos como ele se apresenta. Nesta, a educação cumpre o papel de inserir os seres humanos em suas respectivas funçóes sociais e econômicas, tornando-os cidadãos. Ou seja, o ser humano que se anular e se entregar aos poderes educativos da educaçáo escolar certamente contemplará um resultado positivo em seu futuro (a tal inclusão) e seus esforços e sacrifícios terão valido a pena. Desse modo há, aparentemente, um completo desaparecimento das contradiçóes objetivas do sistema e um reforço deste por meio da própria educaçáo, pois a partir dela existe o caminho certeiro que levará o ser humano a uma boa vida inserindo-se na forma social/econômica produtora, distribuidora e comercializadora de mercadorias. A educação, portanto, aparece como um local privilegiado, absolutamente melhor e infinitamente superior ao mundo material, não obstante, com o único intuito de levar a sua realização (material), pois se apresenta ao ser humano como uma possibilidade de inserçáo na forma material de produção e consumo. Aquele ser tem, com esse discurso ideológico educativo, menos motivos para vislumbrar algum tipo de questionamento da forma atual de organização do mundo; pelo contrário, a possibilidade oferecida pela educaçáo acaba por afirmar tal forma de organizaçáo e ajudar a apagar qualquer sombra ou vislumbre desse questionamento ou crítica. E, por outro lado, a tấo esperada consciência, produzida a partir da educação e com viés revolucionário, não aconteceu - mesmo com sua massificação total, demonstrando que a possibilidade dialética da educação (a de não ser apenas um instrumento de adaptação e de manutenção da realidade, como também de alteração e inconformismo com esta) parece enfraquecida pela real circunstância produtiva.

Consubstancia-se, assim, uma realidade em que os apelativos discursos daqueles entusiastas da educação, da direita ou da esquerda, políticos ou empresários, homens comuns ou intelectuais acadêmicos — mesmo que, muitos deles, cobertos de boas intençóes - , acabam por reforçar o que aparentemente desejam combater: a miséria, a pobreza, a violência, a falta de humanidade, em suma, a própria forma capitalista de produção e reprodução do mundo econômico e social. Porque, ao divulgarem tal discurso, postulando a inserção social por meio da educação escolar, e estimulando as massas a acreditarem nele, ajudam também a fazer com que essas mesmas pessoas creiam na possibilidade de inserir-se na organizaçáo econômica e social capitalista, como produtores e reais consumidores, como se nela houvesse lugar para todos. Com efeito, tal postulado apresenta como factível, por meio unicamente da educação e sem alterar as condições objetivas de produção, a desintegração da clássica apreensão de Marx (1989, p. 502-517), a saber: os problemas causados pelo avanço tecnológico sobre o emprego, o aumento do "exército de reserva" - um elemento fundamental, segundo ele, para, em suma, manter baixos os salários dos trabalhadores empregados - e da complexa engenhosidade das formulaçóes da composição dos salários para conservar rentável a produção — expostas por Marx (1989, p. 617-658). 
Pois, se levarmos em consideração o tão propalado objetivo da empregabilidade e de um número maior de vagas de trabalho mediado unicamente pelo apelo à educação escolar, logo perceberemos a grande falácia inerente a tal propaganda. Não há e nunca haverá crescimento do número de vagas de emprego em qualquer setor da economia devido a uma maior escolarização de sua população, e sim em razão de um crescimento exponencial do mercado consumidor, em que, para dar conta da demanda pelos produtos, apenas o avanço tecnológico não é o suficiente, e a valorização do valor — ou, podemos dizer, a rentabilidade — é factível. E mesmo assim ainda haverá a possibilidade de as vagas criadas serem de trabalho precário, necessitando baixa escolarização e oferecendo salários minúsculos devido à dinâmica interna à formação do capital. A própria condição de empregabilidade conseguida pelos indivíduos ao frequentarem cursos técnicos, universitários ou profissionalizantes, realmente só se efetiva após um longo período de experiência prática na função. A rigor, é fácil constatar que o mercado de trabalho valoriza especialmente a experiência efetiva na função a ser exercida, e não apenas o conhecimento teórico sobre tal função.

Não obstante, ao percebermos e considerarmos tais fatos, também entendemos que os entusiastas da educação, munidos do discurso ideológico "educacionista", mantém-na como cultura afirmativa, numa configuração ainda mais precisa ao conceito de Marcuse (1997, p. 95-96), pois a exaltam como capaz de dissociar-se do mundo material e causar alteraçóes nele, precisamente na forma de produzi-lo (forma produtiva). Esse enaltecimento da educação vai além, mas se mantém afirmativo, no momento em que toma rumos aparentemente dissociados de fins utilitários, isto é, materiais. Nesse momento, a educação, no discurso de seus demiurgos, assume cores correspondentes a um transporte capaz de levar os indivíduos nela envolvidos a locais muito acima do sujo e feio mundo material. Nesse caso, educar-se seria refinar-se, alimentar o espírito, saldar a dívida com a alma, desenvolver um comportamento não violento, preocupar-se com seu semelhante, alcançar o belo, o bom e o justo. Em tal circunstância, há o abandono de qualquer interesse em mudanças na organização social da produção material do mundo, já que a gratificação dos seres humanos emana de elementos espirituais, contidos na democratizada educação escolar, e não nos meios materiais que, a partir disso, podem ser organizados de qualquer maneira em sua produção e distribuição. Porém, mesmo tentando separar-se da materialidade, o enlace não é desfeito, porque a própria cultura afirmativa é produzida pelo contexto da produção material em sua forma capitalista industrial.

\section{Conclusão}

Por meio da educação escolar, os agentes humanos responsáveis por manter a dinâmica da reprodução exponencial do capital parecem conseguir ca- 
muflar as contradiçóes internas e imanentes a essa dinâmica. A ideologia, que historicamente nunca foi um produto das ideias separadas da materialidade da produção da vida, se torna real ao convencer os seres humanos contemporâneos a depositarem todas as suas esperanças de uma vida melhor na movimentação à busca da melhoria de sua própria educação. A direção dessa movimentação é antecipada pela ordem econômica e social, fazendo da profissionalização o único fim da educação e do ser humano, finalizando o homem e reduzindo-o a um ser que apenas produz e consome, um negativo do homem exatamente em uma época que fornece todas as condiçóes para a humanização. Pois é com o avanço tecnológico a passos largos que as chances são cada vez mais factíveis do homem emancipar-se ao fardo do trabalho, alterando as relaçóes de produção e, obviamente, consumo, alcançando, com isso, as condiçóes objetivas para a verdadeira formação, a saber: a liberdade para o conhecimento, uma libertação que atingirá sujeito e objeto. Contudo, a verdade de sujeito e objeto é obstaculizada pela falsidade da necessidade atual de autoconservaçáo materializada em produçáo e consumo sem fins humanos; disso alimenta-se e concretiza-se a semiformação, que nunca foi unicamente ideia ou ideológica, sempre esteve entrelaçada e em relação recíproca com os objetivos da produçáo de mercadorias. Essas, que para serem produzidas ou consumidas prescindem cada vez mais do conhecimento, transformam a educação escolar na própria semiformação, em produto de baixo preço e em franca desvalorização. Fazem isso porque a revolução tecnológica foi transformada também em mercadoria a ser vendida, e porque a espiral descendente de salários e ascendente de mais-valia foi erigida pela mesma revolução. Entretanto, se nada há de verdadeiramente caro para a maioria maciça dos seres humanos, existe uma minoria que desfruta do melhor. Desse modo, no atual momento, a educaçáo escolar pode ter três destinos, a saber:

1. concedida à maioria como véu ideológico, ideacional e semiformativo do capitalismo, fornecendo esperanças falsas de ascensão social sem nenhuma correlação com a objetiva estrutura de produção e reprodução do capital - limitada sempre pela complexa relação entre tecnologia (que praticamente tem um movimento autônomo, independente dos níveis de educação de um povo, como os agentes do capital sempre tentam afirmar) e natureza;

2. concedida para uma minoria substancialmente contribuir para a formação, desvelada e sorvida como desfrute daqueles que, tal qual a elite grega da Antiguidade, possuam o privilégio da scholé; e, por fim,

3. destinada à formaçáo para a emancipação, originando o negativo da semiformaçáo, revelando a ideologia e a crença, disfarçada de ciência, no irracional, e, assim, firmando o compromisso com a racionalidade para alcançar a paz, justiça, beleza e bondade para todos. 


\section{Notas}

1. Cf. www.todospelaeducacao.org.br

2. Tal qual um grupo não identificado, mas que se autointitula "movimento mais feliz", e que conclama a população brasileira a assinar, via internet, uma petição para que uma emenda constitucional seja aprovada e, com ela, a felicidade para todos seja alcançada. Literalmente, há quem acredite em felicidade por decreto.

\section{Referências}

ADORNO, T. W. Educação e emancipação. São Paulo: Paz e Terra, 1995.

Teoria da semicultura. Educação \& Sociedade, Campinas, n. 56, p. 388-411, dez. 1996. Disponível em: $\leq$ http://cev.org.br/biblioteca/educacao-sociedade-1996-n56-v17/>.

ADORNO, T.W.; HORKHEIMER, M. Dialética do esclarecimento. Rio de Janeiro: Jorge Zahar, 2006.

ADORNO, T.W.; HORKHEIMER, M. A indústria cultural. In: ADORNO, T.W.; HORKHEIMER, M. Dialética do esclarecimento. Rio de Janeiro: Jorge Zahar, 2006. p. 99-138.

MAAR, W.L. A produção da "sociedade" pela indústria cultural. Olhar, ano 2, n. 3, p. 2-24, jun. 2000. Disponível em: <http://www.ufscar.br/-revistaolhar/pdf/olhar3/07Adorno. pdf $>$. Acesso em: 15 mar. 2016.

. Adorno, semiformação e educação. Educação \& Sociedade, Campinas, v. 24, n. 83, p. 459-476, ago. 2003. Disponível em: <http://www.scielo.br/pdf/es/v24n83/a08v2483. pdf>. Acesso em: 10 mar. 2016.

MARCUSE, H. Sobre o caráter afirmativo da cultura. In: Cultura e sociedade. São Paulo: Paz e Terra, 1997. p. 89-135.

MARX, K. A ideologia alemã. São Paulo: Hucitec, 1991.

. O capital. Rio de Janeiro: Bertrand Brasil, 1989. v. 1.

RINGER, F.K. O declinio dos mandarins alemães. São Paulo: Edusp, 2000.

Recebido em 17 de maio de 2016.

Aceito em 18 de julho de 2017. 